\title{
IRON AND PROTEIN KINETICS STUDIED BY MEANS OF DOUBLY LABELED HUMAN CRYSTALLINE TRANSFERRIN *
}

\author{
BY JAY H. KATZ \\ (From the Radioisotope and Medical Services of the Boston Veterans Administration Hospital, \\ and the Dept. of Medicine, Boston University School of Medicine, Boston, Mass.)
}

(Submitted for publication June 16, 1961 ; accepted August 10, 1961)

Although proteins isotopically labeled with iodine have been used in tracer studies for some years, interest has been mainly focused on their distribution and degradation in the body. While it is often possible to produce iodoproteins whose physical and chemical properties are not grossly altered, the possible effects of iodination on the functional properties of such substances in a physiologic setting have been less thoroughly investigated. That it is possible to trace label proteins without significantly reducing their biological activities has been demonstrated in the case of insulin (2) and certain anterior pituitary hormones $(3,4)$.

Transferrin (siderophilin, iron-binding globulin), a $\beta$-globulin found in the plasma of man $(5,6)$ and other animal species $(7,8)$, is thought to function primarily as a transport vehicle for iron (9). It is remarkably similar in its metalbinding properties to conalbumin, an egg white pseudoglobulin, and, indeed, it has been suggested that the binding sites in the two proteins are similar (10). At neutral or mildly alkaline $\mathrm{pH}$ and in the presence of bicarbonate, both proteins firmly bind two ferric ions per molecule, forming colored complexes which have approximately the same absorption maximum (11-14).

It has been shown that the iron-binding capacity of uncomplexed conalbumin is markedly diminished by a variety of chemical procedures which include iodination. This suggests that the specific interaction between metal and protein depends on the structural integrity of the latter (15). However, Azari and Feeney $(16,17)$ have recently

* A preliminary report of this study has appeared in abstract form (1). This work was supported by Training Grant no. 2A-5155 from the National Institute of Arthritis and Metabolic Diseases of the United States Public Health Service to the Boston University School of Medicine. demonstrated that not only is the iron complex of conalbumin more resistant to proteolysis and thermal denaturation than the metal-free protein, but that it is possible to maintain the iron-binding capacity of the former after extensive iodination.

Since both iron and transferrin levels are affected in a variety of disease states, a technique in which both can be followed simultaneously in vivo should prove valuable. Elmlinger and coworkers (18) have reported in abstract form on the use of doubly labeled "iron-binding globulin" in human subjects, but few details were given as to the methods of preparation and the distribution of the two labels.

The following study was undertaken to determine if the protein moiety of the iron-transferrin complex could be labeled with iodine without affecting its binding properties. When this was found to be possible in vitro, the behavior of the doubly labeled crystalline transferrin was then investigated in eight normal subjects.

\section{METHODS}

Three times recrystallized human transferrin was obtained in its iron-free form ${ }^{1}(19,20)$. This material was at least 97 per cent pure, by moving boundary electrophoretic criteria. A similar preparation has been shown to have 0.5 per cent albumin and 0.2 per cent $\gamma$-globulin, as determined immunologically (21). Starch gel electrophoresis of this material at $\mathrm{pH} 8.5$, using the method of Smithies (22), yielded a single band corresponding to the transferrin $C$ phenotype (23).

All glassware was acid-washed. Iron was added as $\mathrm{Fe}\left(\mathrm{NH}_{4}\right)_{2}\left(\mathrm{SO}_{4}\right)_{2} \cdot 6 \quad \mathrm{H}_{2} \mathrm{O}$ (with or without $\mathrm{Fe}^{59}$ ) to solutions of the protein at $\mathrm{pH} 7.5\left(0.1 \mathrm{M}\right.$ Tris, ${ }^{2} 0.02 \mathrm{M}$ $\mathrm{HCO}_{3}^{-}$). After stirring for 1 hour at room temperature, the mixture was allowed to stand overnight at 4 to $5^{\circ} \mathrm{C}$ to allow sufficient time for oxidation of the ferrous ion

${ }^{1}$ Kindly provided by the Michigan State Department of Health through the courtesy of the American Red Cross.

2 Sigma 121; tris (hydroxymethyl)aminomethane. 
and full color development. A 20 to 40 per cent excess of iron was used when complete saturation was desired. Optical titrations (6) were carried out in the same buffer by adding varying amounts of iron to equal aliquots of protein. The resultant solutions were checked at intervals to determine if maximal color development had been attained; generally the final readings were not taken for 18 hours.

Iodination was carried out as follows : 8 to 10 per cent solutions of transferrin (iron-saturated or iron-free) were first thoroughly dialyzed against $0.1 \mathrm{M}$ Tris buffer to bring the $\mathrm{pH}$ to 8.5 and to remove excess iron. Iodine was added dropwise with constant stirring to samples of the protein kept in an ice bath. The iodinating solutions contained $\mathrm{I}_{2}$ and $\mathrm{KI}$ in a molar ratio of $1: 2$ or $1: 4$ plus carrier-free $\mathrm{KI}^{131}$. Because of the presence of bisulfite in commercial $\mathrm{KI}^{131}$, the molarity of the iodine was checked immediately before use by titration against arsenate. After addition of the required amount of the iodine, the mixtures were allowed to stand in the ice bath for 4 to 6 hours and then passed slowly through a Dowex-1 column $\left(\mathrm{Cl}^{-}\right.$cycle, buffered at $\mathrm{pH} 8.5$ with $0.01 \mathrm{M}$ Tris $)$. This removed 98 to 99 per cent of the excess $\mathrm{I}^{-}$. When extinction coefficients were to be determined, the solutions were then dialyzed thoroughly against several changes of $0.02 \mathrm{M}$ Tris, $0.1 \mathrm{M} \mathrm{NaCl}, \mathrm{pH} 7.5$ buffer. Dry weights (determined in duplicate) were determined by lyophilization of duplicate aliquots in a vacuum oven at $65^{\circ} \mathrm{C}$ until constant weight was achieved. The weight of the salt in the final dialysate was subtracted to give the net weight of protein. No Donnan correction was made. The optical density was read against a dialysate blank.

For purposes of stoichiometry the reaction was presumed to proceed as follows : $\mathrm{I}_{3}^{-}+\mathrm{R} \rightarrow \mathrm{RI}+2 \mathrm{I}^{-}$.

It should be noted that when iodine ( 2 equivalents per mole) and iodide are present in the iodinating mixture in a molar ratio of $1: 2$, a maximum of 25 per cent of the added radioactivity will be bound if the above reaction goes to completion, assuming that the labeled iodide is in ready equilibrium with the stable triiodide ion. Thus, the iodine content of the transferrin may be calculated from the radioactivity of the protein per unit weight, with reference to the specific activity of the iodinating solution expressed in terms of counts per equivalent of total iodine plus iodide. It was in fact demonstrated that the specific activity of the labeled transferrin was within 6 per cent of that of the iodinating mixture by means of direct chemical determinations of each in two experiments. $^{3}$ In these calculations the molecular weight of transferrin was taken as 86,000 . The yield, as given in the results, compares the actual iodine content per mole of protein with that of the theoretical maximum under a given set of conditions.

When prepared for injection, transferrin was initially saturated with stable iron and, after iodination as above with a total of 2 to $3 \mathrm{mc} \mathrm{I} \mathrm{I}^{131}$, the iron was removed by

\footnotetext{
3 These determinations were performed by the Graham Laboratories, Brookline, Mass.
}

lowering the $\mathrm{pH}$ to 5.5 to 5.6 with an acetate-EDTA * buffer (19). Decolorization of the complex was complete in 1 hour; the solutions were then dialyzed to bring the $\mathrm{pH}$ back to 7.5 and to remove the EDTA. $\mathrm{Fe}^{5 \theta}$ was then added to the desired level of saturation. After further dialysis against $0.02 \mathrm{M} \mathrm{NaHCO}_{3}, 0.1 \mathrm{M} \mathrm{NaCl}(\mathrm{pH}$ 7.4 to 7.6), the solution was passed through a Millipore filter ${ }^{5}$ (pore size $0.3 \mu$ ) into sterile containers. The final concentration of protein was 2.5 to $4.0 \mathrm{~g}$ per $100 \mathrm{ml}$. It contained 12 to $25 \mu \mathrm{c}$ of $\mathrm{I}^{131}$, and 1 to $2 \mu \mathrm{c}$ of $\mathrm{Fe}^{58}$ per $\mathrm{ml}$. Less than 0.1 per cent of the iodine radioactivity was unbound as determined by trichloroacetic acid precipitation.

Processing took 3 days and the material was administered within 5 days of the initial addition of $\mathrm{I}^{131}$. It was calculated (24) that no more than 3,000 rad was absorbed by the transferrin prior to injection.

Analytic ultracentrifugal patterns were obtained in a model E Spinco ultracentrifuge. ${ }^{6}$ The human transferrin immune serum used was derived from rabbits ${ }^{7}$ and was found to produce a single band of precipitation against serum and crystalline transferrin in Ouchterlony (25) plates. Quantitative precipitin curves in the zone of antibody excess were constructed by the method of Gitlin (26).

Chromatograms were done on Whatman no. 1 paper using the salt-saturated solvent (A) described by McMenamy, Lund and Oncley (27). Digests were prepared in $4 \mathrm{M} \mathrm{Ba}(\mathrm{OH})_{2}$ in sealed tubes at $105^{\circ} \mathrm{C}$. The papers were stained with either Pauly's reagent or isatin, as described by the same authors. Monoiodotyrosine (Rf, 0.41) and diiodotyrosine (Rf, 0.19) reacted with both these stains, although less well than tyrosine itself. In addition to visual estimation against standards, the iodinated protein chromatograms were scanned in a strip counter or radioautographed.

The volunteers used in the in vivo studies were all healthy white males, 25 to 43 years of age. All received 10 drops of Lugol's solution daily. The doubly labeled transferrin was delivered intravenously from calibrated syringes from which standards were also prepared. The total amount of protein and iron injected did not exceed $70 \mathrm{mg}$ and $90 \mu \mathrm{g}$, respectively (about 2 to 3 per cent of the total plasma content of each). Each subject received 30 to $50 \mu \mathrm{c}$ of $\mathrm{I}^{131}$ and 3 to $4 \mu \mathrm{c}$ of $\mathrm{Fe}^{50}$.

Six to $7 \mathrm{ml}$ of blood was drawn at 10 - to 30 -minute intervals for the first 3 hours and approximately 6 hours after injection and the plasma immediately separated. Daily samples were taken thereafter for 18 to 21 days and, in addition to plasma, aliquots of whole blood, hemolyzed with saponin, were saved for counting. Serum iron and total iron-binding capacity (TIBC) were determined on samples drawn immediately before injection of transfer-

${ }^{4}$ Ethylenediamine tetraacetic acid (disodium salt).

5 Millipore Corporation, Bedford, Mass.

${ }^{6}$ Kindly performed through the courtesy of Dr. J. L. Oncley and Mr. Charles Gordon, Dept. of Biological Chemistry, Harvard Medical School.

${ }^{7}$ Behringwerke, Marburg-Lahn, West Germany. 
rin and about 2 weeks later. The method of Peters, Giovanniello, Apt and Ross (28-30) was used for both.

Radioactivity was measured in a sodium iodide scintillation well counter. Simultaneous $\mathrm{Fe}^{50}$ and $\mathrm{I}^{131}$ content was determined using an adaptation of the method of Hine and associates (31) in which two scalers, set at different discrimination levels (200 and $700 \mathrm{Kev})$, were employed. The sample counts are then compared to pure $\mathrm{Fe}^{58}$ and $\mathrm{I}^{131}$ under identical conditions. By means of the comparative counting sensitivities of the scalers, simultaneous equations may be derived which define the relative proportions and absolute amounts of the two isotopes in the mixed sample. This method yields a higher counting rate than would be obtained by using a narrow-window pulse-height analyzer. Net counting rate on the scaler with the lower discriminator setting was at least three times background, and sufficient counting time was employed to give an over-all counting error of not more than 3 to 4 per cent.

Body counting was performed with the apparatus described by Hine, Jagger and Burrows (32). The recording system was as described above, except that a correction was made for the difference in geometry between standards and the body.

The terms and methods of calculation used for iron kinetics are those of Huff and co-workers (33). Venous hematocrit was corrected by a factor of 0.92 in calculating red cell mass. Plasma volume was determined on the basis of the dilution of $\mathrm{I}^{131}$ as extrapolated to zero time. Transferrin concentration of plasma in milligrams per $100 \mathrm{ml}$ was calculated as TIBC $(\mu \mathrm{g}$ per $100 \mathrm{ml}) / 1.30$. Immunologic determinations of transferrin concentration agreed closely with the above.

\section{RESULTS}

A. Chemical studies. The addition of iodine to both iron-free and iron-saturated transferrin was practically quantitative, 89 to 98 per cent of the theoretical yields being obtained. This is apparently due to the large number of tyrosine residues present (about 30 per mole on the basis of chromatographic estimation) and the absence of reduced sulfhydryl groups in the transferrin molecule (34).

The original transferrin, fully saturated with iron, had a broad visible absorption maximum with a peak at $465 \mathrm{~m} \mu$ where the extinction coefficient $\left(\mathrm{E}^{1 \%}{ }_{46 \mathrm{~s}}\right)$ was $0.63 .^{8}$ Optical titration at this wave length indicated a binding capacity of 1.30 Fe per mg transferrin, equivalent to a molecular weight of 86,000 for the protein. The same value was obtained by means of the specific activity of

8 When corrected for the absorption of the iron-free transferrin at this wave length, as is done by Inman and colleagues $(20), \mathrm{E}^{1 \%} \%_{48 ;}$ is 0.60 .
TABLE I

Effect of iodination of iron-saturated transferrin on the visible extinction and binding capacity *

\begin{tabular}{ccc}
\hline \hline $\begin{array}{c}\text { Moles I/ } \\
\text { mole } \\
\text { transferrin }\end{array}$ & $\mathrm{E}^{1 \%} \%_{465}$ & $\begin{array}{c}\text { Binding } \\
\text { capacity } \\
(\mu \mathrm{ge} / \mathrm{Fg}) \\
\text { transferrin }\end{array}$ \\
\hline 0.0 & 0.63 & 1.30 \\
0.9 & 0.63 & 1.31 \\
2.0 & 0.63 & 1.29 \\
5.7 & 0.63 & 1.33 \\
9.2 & 0.62 & 1.29 \\
14.0 & 0.61 & 1.28
\end{tabular}

* All of the above were iodinated as the iron complex. Values were obtained after dialysis and treatment with cation-exchange resin, $\mathrm{pH}$ 7.5.

$\mathrm{Fe}^{59}$ in samples that were first passed through a cation-exchange column, which removes traces of nonchromogenically bound iron.

The effect of iodination on the visible extinction of transferrin and its iron-binding capacity is shown in Table I. Only a slight change was noted when up to 14 atoms of iodine per mole of protein were incorporated into the iron-complexed protein. In contrast, a moderate but progressive decrease in $\mathrm{E}^{1 \%}{ }_{465}$ was noted when iron-free transferrin was iodinated and subsequently saturated with iron (Table II).

The ultraviolet spectrum in $0.1 \mathrm{~N} \mathrm{NaOH}$ was little changed in the region of $279 \mathrm{~m} \mu$, but increasing absorption was noted in the region of 308 to $312 \mathrm{~m} \mu$ as the iodine content of the transferrin was increased. Although this appeared to indicate the presence of diiodotyrosine, which has its absorption maximum at $311 \mathrm{~m} \mu$, chromatographic analysis of the iodoproteins indicated that all of the radioactivity moved as monoiodotyrosine. Evidently the absorption maximum of monoiodoty-

TABLE II

Effect of iodination of iron-free transferrin on the visible extinction after subsequent iron saturation*

\begin{tabular}{cc}
\hline $\begin{array}{c}\text { Moles I/ } \\
\text { mole } \\
\text { transferrin }\end{array}$ & $\mathrm{E}^{1 \% 465}$ \\
\hline 0.0 & 0.63 \\
0.7 & 0.59 \\
1.5 & 0.58 \\
5.1 & 0.54 \\
8.5 & 0.51
\end{tabular}

* All of the above were iodinated in the iron-free state. The extinctions were obtained after addition of excess iron, followed by dialysis. Binding capacity was not determined as such in this series. 
rosine, which is $305 \mathrm{~m} \mu$ in basic solutions, is increased somewhat in the peptide chain.

When lightly iodinated transferrin ( 0.9 atoms iodine per mole) saturated with $\mathrm{Fe}^{59}$ was dialyzed at room temperature for 48 hours against a large volume of human serum, no radioiodide appeared in the dialysate. The great stability of the iron protein complex was indicated by the fact that only 9 per cent of the theoretical amount of iron that could be bound by the transferrin in the serum crossed the membrane in the 48 hours.

Iron was removed from this preparation by lowering the $\mathrm{pH}$ to 5.6 in the presence of EDTA. After EDTA was eliminated by dialysis and the $\mathrm{pH}$ raised to 7.5 , the binding capacity was unchanged. $E^{1 \%}{ }_{279}$ of the iron-free material was 11.1 and that of the iron-saturated protein 13.7, which were the same as the values of the uniodinated transferrin.

Ultracentrifugation of the lightly iodinated ${ }^{-}$ transferrin in $0.15 \mathrm{M} \mathrm{NaCl}, 0.01 \mathrm{M}$ Tris, $\mathrm{pH} 7.5$, gave patterns which were identical with that of the original protein. Sedimentation of a 1 per cent solution of iron-saturated transferrin at $25^{\circ} \mathrm{C}$ was 5.1S (Figure 1). Immunologic studies on this material revealed no obvious alteration in either the precipitation patterns produced in Ouchterlony plates or in the quantitative precipitin curves as compared with normal human serum and untreated crystalline transferrin.

$B$. In vivo studies. Four separate preparations of iodinated transferrin, each doubly labeled, were used in these studies: I) 0.4 atoms iodine per mole and $1.32 \mu \mathrm{g} \mathrm{Fe}$ per $\mathrm{mg}$ transferrin (100 per cent saturation), II) 0.8 atoms iodine per mole and $1.3 \mu \mathrm{g} \mathrm{Fe}$ per mg transferrin (100 per cent saturation), III) 0.6 atoms iodine per mole and 0.57 $\mu \mathrm{g} F \mathrm{Fe}$ per $\mathrm{mg}$ transferrin (42 per cent saturation), IV) 0.6 atoms iodine per mole and $0.65 \mu \mathrm{g} \mathrm{Fe} \mathrm{per}$ $\mathrm{mg}$ transferrin ( 50 per cent saturation). All were prepared from the same lot of crystalline transferrin.

Ferrokinetic data in the eight subjects are summarized in Table III. Since relatively small amounts of $\mathrm{Fe}^{59}$ were injected, plasma clearance could be accurately followed for only 3 to 6 hours

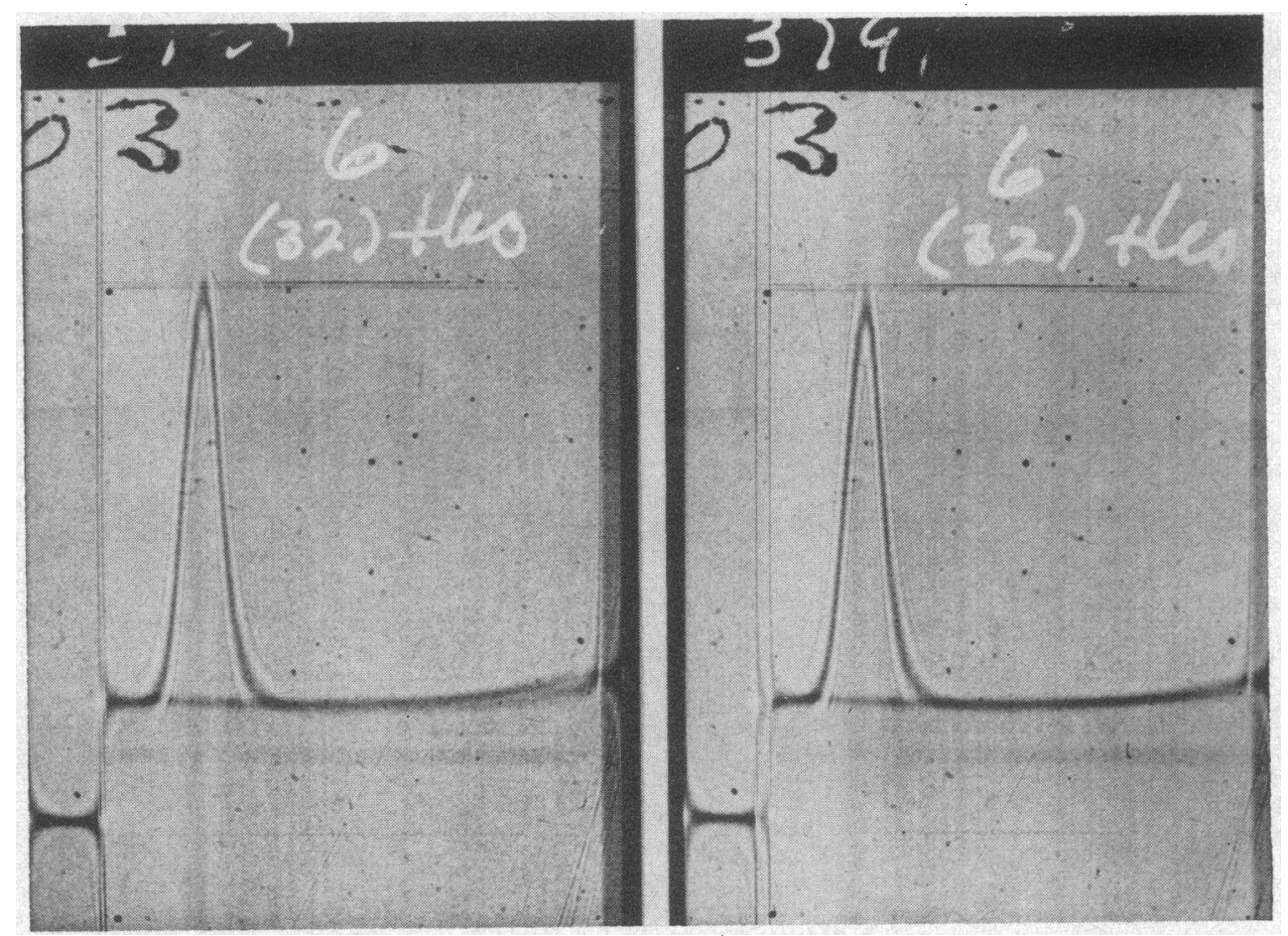

Fig. 1. Ultracentrifugal patterns of CRystalline transferrin, 0.99 G PER 100 ML (LEFT) AND OF IODINATED TRANSFERrin WITH 0.9 ATOMS IOdINE PER MOLE PROTEIN, 0.96 G PER $100 \mathrm{ML}$ (RIGHT). Both preparations saturated with iron and dialyzed against a $\mathrm{pH} 7.5,0.15 \mathrm{M}$ $\mathrm{NaCl}, 0.01 \mathrm{M}$ Tris buffer, $59,780 \mathrm{rpm}$; bar angle $+60^{\circ}$, time 32 minutes, temperature $25^{\circ} \mathrm{C}$. 
TABLE III

Ferrokinetics of doubly labeled transferrin

\begin{tabular}{|c|c|c|c|c|c|c|c|}
\hline Subject & Preparation & $\begin{array}{l}\text { Venous } \\
\text { het. }\end{array}$ & $\underset{\mathrm{Fe}}{\text { Plasma }}$ & $\mathrm{T}_{\frac{1}{3}} \mathrm{Fe}^{*}$ & $\begin{array}{c}\text { Plasma } \\
\text { Fe } \\
\text { turnover }\end{array}$ & $\underset{\text { utilization }}{\mathrm{RBCFe}}$ & $\begin{array}{l}\mathrm{RCB} F e \\
\text { turnover }\end{array}$ \\
\hline H.L. & I & $\begin{array}{l}\% \\
45\end{array}$ & $\begin{array}{c}\mu \mathrm{g} / 100 \mathrm{ml} \\
94\end{array}$ & $\begin{array}{l}\text { hrs } \\
1.05\end{array}$ & $\begin{array}{c}m g / k g / d a y \\
0.67\end{array}$ & $\begin{array}{c}\% \text { dose } \\
86\end{array}$ & $\begin{array}{c}m g / \mathrm{kg} / \mathrm{day} \\
0.58\end{array}$ \\
\hline R.M. & I & 47 & 124 & 1.32 & 0.69 & 85 & 0.56 \\
\hline A.D. & II & 45 & 163 & 2.48 & 0.48 & 75 & 0.36 \\
\hline H.W. & II & 47 & 86 & 0.98 & 0.63 & 92 & 0.59 \\
\hline E.M. & III & 46 & 130 & 1.63 & 0.58 & 81 & 0.48 \\
\hline P.R. & III & 45 & 146 & 2.00 & 0.52 & 81 & 0.42 \\
\hline H.C. & III & 44 & 123 & 2.00 & 0.49 & 85 & 0.42 \\
\hline S.M. & IV & 48 & 89 & 1.93 & 0.34 & 87 & 0.30 \\
\hline
\end{tabular}

* Half-life of plasma iron disappearance.

after injection. During this interval the iron disappeared at what seemed to be a single exponential rate. With the exception of A.D., whose serum iron was at the upper limit of normal, it appeared that the clearance was more rapid in those subjects given transferrin fully saturated with iron. Variation in serum iron levels makes direct comparison difficult, since the calculated plasma iron turnover values diminished the apparent differences, although the three highest values for turnover were found in those subjects given preparations I and II. However, all values were within the limits previously established in this laboratory $(35,36)^{9}$ and in others $(37,38)$ when whole plasma has been used to bind the radioiron.
Red cell utilization of iron was maximal on the eighth to tenth day after injection, at which time 75 to 92 per cent of the $\mathrm{Fe}^{59}$ was in the circulating red cell mass. This is again within the range found when plasma-bound iron is injected. ${ }^{9}$

Protein kinetics are summarized in Table IV. The initial rate of disappearance of transferrin from the plasma (over the first 3 to 6 hours) did not exceed 5.7 per cent per hour, i.e., the half-life

9 The values obtained in this laboratory in normal subjects using whole plasma to bind radioiron have been: a) plasma iron half-life $\left(\mathrm{T}_{1} \mathrm{Fe}\right), 1.0$ to 2.4 hours; $b$ ) plasma iron turnover, 0.25 to $0.70 \mathrm{mg}$ per $\mathrm{kg}$ per day ; $c$ ) maximal red blood cell $\mathrm{Fe}$ utilization, 75 to 95 per cent of dose injected.

TABLE IV

Protein kinetics of doubly labeled transferrin

\begin{tabular}{|c|c|c|c|c|c|c|c|c|}
\hline Subject & Wt & $\underset{\text { transferrin }}{\text { Plasma }}$ & $\begin{array}{l}\text { Plasma } \\
\text { volume }\end{array}$ & $T_{\frac{1}{2}} ; *$ & $\begin{array}{c}\text { Total } \\
\text { transferrin } \\
\text { pool }\end{array}$ & $\begin{array}{c}\text { Extra- } \\
\text { vascular } \\
\text { fraction of } \\
\text { transferrin } \\
\text { pool }\end{array}$ & $T_{1}, n t$ & $\begin{array}{c}\text { Transferrin } \\
\text { degraded } \\
\text { per day }\end{array}$ \\
\hline & $k g$ & $m g \%$ & $\mathrm{ml} / \mathrm{kg}$ & hrs & $\mathrm{g} / \mathrm{kg}$ & & days & $\mathrm{g} / \mathrm{kg}$ \\
\hline H.L. & 45.6 & 255 & 45 & 21 & 0.27 & 0.57 & 8.0 & 0.023 \\
\hline R.M. & 71.0 & 256 & 44 & 16 & 0.30 & 0.62 & 7.0 & 0.030 \\
\hline A.D. & 90.5 & 205 & 44 & 18 & 0.20 & 0.56 & 7.5 & 0.019 \\
\hline H.ll. & 53.6 & 222 & 43 & 14 & 0.25 & 0.62 & 7.8 & 0.022 \\
\hline E.M. & 77.5 & 213 & 44 & 23 & 0.23 & 0.58 & 6.7 & 0.024 \\
\hline P.R. & 60.8 & 236 & 48 & 15 & 0.29 & 0.61 & 7.5 & 0.027 \\
\hline H.C. & 55.0 & 215 & 47 & 15 & 0.25 & 0.59 & 7.7 & 0.023 \\
\hline S.M. & 70.5 & 246 & 44 & 12 & 0.27 & 0.59 & 8.4 & 0.022 \\
\hline
\end{tabular}

* $T_{3 i}=$ half-life of initial plasma transferrin disappearance (diffusion).

$\dagger T_{i p}=$ plasma half-life of transferrin after equilibrium was achieved (degradation). 
of this initial disappearance $\left(T_{11}\right)$ was greater than 12 hours. This is about the same rate at which albumin initially diffuses from the plasma (39). No significant difference was noted in the four preparations used. Plasma volumes obtained by extrapolating iodine counts to zero time were likewise similar to those obtained by others when radioalbumin was used (40). Indeed, in two subjects Evans blue plasma volume determinations were within 8 per cent of the isotope dilution volumes.

In all subjects, zero time $\mathrm{I}^{131}$ and $\mathrm{Fe}^{58}$ counts, expressed as the fraction of the respective isotope injected, agreed quite closely (Figure 2A). Graphical analysis of curves constructed from plasma transferrin disappearance over the ensuing 3 days (Figure 2B) indicated that the initial rate of dif-

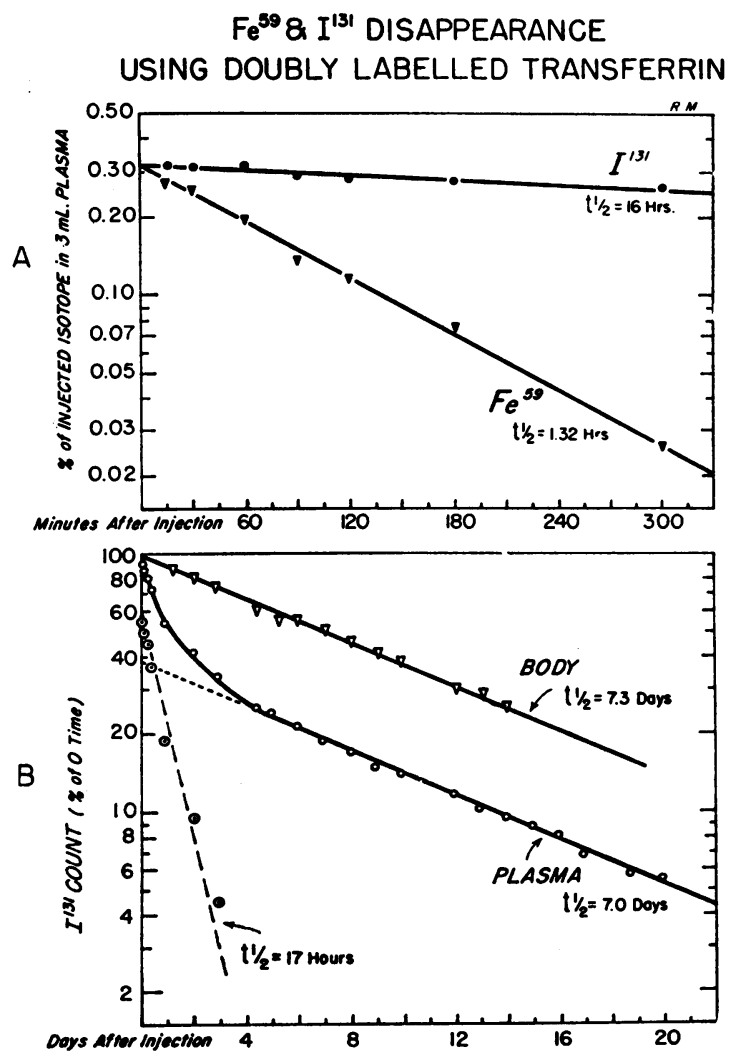

Fig. 2. A) Disappearance of FE ${ }^{50}$ AND $I^{181}$ From the PLASMa in SUbJect R.M. OVER THE FIRST 5 hOURS AFTer INJECTION, PLOTTED ON SEMILOGARITHMIC SCALE. Abscissa units are in minutes. B) DISAPpeARANCE of I ${ }^{131}$ FROM THE PLASMA AND "BODY" IN R.M. Abscissa units are in days. The dashed line in the lower left-hand corner represents the initial component of plasma disappearance as extrapolated from the linear portion of the plasma curve. fusion did not vary significantly and corresponded to the rate observed over the first few hours. Although this apparently indicates that plasma transferrin interchanges with a single extravascular compartment (41), the presence of additional small or very slowly turned over compartments cannot be excluded from the available data. Equilibrium of the tracer in the plasma with such a compartment or compartments was achieved in 4 to $\mathbf{5}$ days. Thereafter the protein disappeared at a single exponential rate with a half-life of 6.7 to 8.4 days (the half-life obtained from Days 5 to 12 did not differ significantly from the half-life obtained by including subsequent points). Extrapolation of this linear portion of the curve to zero time indicated that 56 to 62 per cent of the total exchangeable transferrin was extravascular.

Body counting of radioiodine (Figure 2B) in two subjects gave disappearance rates which were in fair agreement with that obtained from the linear phase of the plasma curves (in H.L. plasma and body half-lives were 8.0 and 8.7 days and in R.M. 7.0 and 7.3, respectively). No evidence of localization of radioiodide was found in the region of the thyroid. Previous observations using radioiodinated albumin have indicated that body-counting disappearance curves closely paralleled those derived from urinary and fecal excretion data (42). It is therefore felt that the plasma data in this study gave a good estimate of the actual degradation rate.

The total exchangeable pool of transferrin ranged from 0.23 to $0.30 \mathrm{~g}$ per $\mathrm{kg}$ body weight. On this basis 0.022 to $0.030 \mathrm{~g}$ was degraded per day per $\mathrm{kg}$. Since transferrin levels were reasonably stable (levels did not vary by more than 10 per cent during the period of study), a steady state may be assumed and the same figures would apply to the synthetic rate.

\section{DISCUSSION}

The great avidity of transferrin for iron appears to account for its primary function as a regulator of the metabolism of the metal in the body. The concentration of ionic iron in the presence of transferrin is exceedingly small provided the binding capacity has not been exceeded. The stability constant of the complex has been estimated as $10^{29}$ (43). Recent evidence has suggested that it may 
play an important part in the control of absorption of iron from the gut (44). Furthermore, the interaction of the protein at specific cellular sites may determine the distribution and chemical form of the iron incorporated into such tissues as marrow and liver $(45,46)$. The studies presented herein indicate that the protein moiety of the transferrin-Fe complex can be labeled with radioiodine without changing its binding properties in vitro. Gross physical and immunologic characteristics were likewise unchanged. It was felt, therefore, that such a substance could be validly employed as a tracer in vivo when both iron and protein kinetics were to be followed.

Dialysis studies indicated that there is a very slow interchange of iron with unsaturated transferrin once the metal is bound within a given molecule. A similar observation has been made recently by Turnbull and Giblett (47) who have employed electrophoretically separable variants of transferrin. It is, therefore, a reasonable assumption that the two isotopes remain on the same transferrin molecule until the iron is removed, there being essentially no interchange of the latter with indigenous protein during the first few hours after injection.

Bothwell, Hurtado, Donohue and Finch (38) found that iron disappearance was significantly slower in subjects given radioiron bound to fraction IV-7 of Cohn as compared with simultaneously determined clearances using iron bound to plasma. The crystalline transferrin used in the present study is derived from fraction IV-4, the immediate source of fraction IV-7 (20). However, the plasma clearance and red cell utilization in the eight subjects studied was within the relatively wide range found by these workers and others (35-37) when plasma-bound iron is injected. It is realized that comparison with previous data of this sort is somewhat tenuous in view of the variability of these values, not only among different subjects but for the same individual at different times. The use of a double-iron isotope technique employing $\mathrm{Fe}^{55}$ and $\mathrm{Fe}^{59}(38,47)$, which might have allowed the direct assessment of any differences in clearance, was precluded by the lack of suitable equipment and the desire to minimize radiation dosage. While it cannot therefore be stated with certainty that there was no alteration in the unloading and normal distribution of iron in vivo, the results suggest that these characteristics are not grossly affected by the methods employed in the isolation and iodination of transferrin.

The observation that transferrin disappears from the plasma compartment much more slowly than the rate at which iron is cleared is similar to the findings of Elmlinger and associates (18), and is consistent with the hypothesis of Laurell that iron is dissociated from transferrin prior to the passage of the protein through the capillaries (9). However, the latter author stated that the process by which this dissociation occurs involves a simple equilibrium between intra- and extravascular ionic iron. In view of the strength of binding, as noted above, it is difficult to see how such a process can account for the rapidity with which iron disappears from the plasma.

Jandl, Inman, Simmons and Allen (45) have indicated that transferrin in some manner preferentially directs iron into hemoglobin-synthesizing reticulocytes in the presence of mature red cells. They suggested that this depends on a specific interaction of transferrin with the surface of reticulocytes. Recent studies employing a preparation of transferrin identical with those used in this report appear to confirm this hypothesis (48).

If such adsorption occurs on erythropoietic cells in general, another possible explanation for the discrepant rates of iron and protein disappearance may be inferred. Bone marrow sinusoids, which are intimately dispersed throughout erythropoietic tissue, appear to be lined by multifunctional reticular cells, to lack a definite basement membrane, and to be frequently discontinuous $(49,50)$. Furthermore, the marrow does not contain separate lymphatic vessels, the sinusoids presumably subserving this function. The circulation is therefore "fundamentally open in character" (49). Thus, transferrin may be directly absorbed from and eluted into the functional confines of the vascular compartment. Since the turnover rates of adsorbed transferrin in reticuloyctes have been found to be quite rapid (48), probably only a small fraction of the transferrin molecules present in this compartment is adsorbed (i.e., sequestered) at any given time, at least in normal subjects. Therefore, no great effect on plasma volume would be noted when determined by dilution of the protein tracer. The clearance of iron may 
thus be a function both of the rate of turnover of the adsorbed Fe-transferrin complex and the rate of extraction of the metal therefrom by the developing red cells. Some evidence that these two rate processes are interrelated has been obtained from the in vitro studies cited above (48). In any event, the extravascular migration of iron in the complexed or ionic state need not be involved.

More than 50 per cent of the exchangeable pool of transferrin was found to be extravascular. Part of this extravascular protein can be found within the cells of various tissues (51). The relatively rapid changes seen in the iron-binding capacity of plasma, which occur in infection, may be a result of redistribution of the transferrin pool. In this regard, Cartwright, Gubler and Wintrobe (52) have found that the reticuloendothelial blockade produced by thorium dioxide inhibits the fall in transferrin level usually noted in infected dogs. Similarly, the increase in plasma transferrin found in iron-deficient states may represent shifts in the opposite direction. The extremely rapid changes observed by Mitchell and co-workers (53) when iron is given in such a situation can only be explained on the basis of redistribution of the transferrin. As indicated by these authors, this may well be due to an increase in transferrin adsorption to cellular sites.

The turnover of transferrin as obtained in this study lay between that observed for albumin (54) on the one hand, and the lipoproteins (55) on the other. Gitlin, Janeway and Farr (56), who also used iodine-labeled crystalline transferrin, found that the metabolic half-life was 12 days in one normal child.

Not only may the procedures employed in obtaining fractions for labeling affect the degradation rates of the protein, but other factors, such as the extent of iodination (57) and the degree of absorption of radiation $(54,58)$, affect its behavior in the body. Although care was taken to minimize the latter factors, it is impossible to state how closely the turnover of the transferrin used in this study corresponds to that of the native protein. However, the fact that several preparations disappeared at an apparently uniform and reproducible rate over 3 weeks, during which time more than 75 per cent of the labeled transferrin had been degraded, suggests that no significant degree of catabolic heterogeneity had been produced.

\section{SUM MARY}

1. Iodine may be incorporated in small amounts into transferrin in its iron-complexed state without materially affecting its binding capacity and immunologic properties in vitro.

2. Iron and protein kinetics were followed in eight subjects after the administration of human crystalline transferrin labeled with both $\mathrm{Fe}^{59}$ and $\mathrm{I}^{131}$.

3. Iron clearance and red cell utilization were within the limits found in previous studies which have used radioiron bound to plasma. Initial transferrin disappearance from plasma was at least six times slower than the rate at which iron was cleared.

4. The total exchangeable pool of transferrin was determined as 0.2 to $0.3 \mathrm{~g}$ per $\mathrm{kg}$ body weight, of which 56 to 62 per cent was extravascular.

5. The metabolic half-life of four separate preparations of iodinated transferrin varied from 6.7 to 8.4 days.

\section{ACKNOWLEDGMENT}

The author is indebted to Dr. Margaret Hunter, Department of Biological Chemistry, Harvard Medical School, and to Dr. Martha Ludwig, Massachusetts Institute of Technology, for their valuable advice and assistance.

\section{REFERENCES}

1. Katz, J. H. Iron and protein kinetics studied by means of doubly-labeled crystalline transferrin (abstract). J. clin. Invest. 1961, 40, 1053.

2. Elgee, N. J., Williams, R. H., and Lee, N. D. Distribution and degradation studies with insulin- $\mathrm{I}^{\text {Is1 }}$. J. clin. Invest. 1954, 33, 1252.

3. Sonenberg, M., Money, W. L., Keston, A. S., Fitzgerald, P. J., and Godwin, J. T. Localization of radioactivity after administration of labeled prolactin preparations to the female rat. Endocrinology 1951, 49, 709.

4. Sonenberg, M., Money, W. L., Dorans, J. F., Lucas, V., and Bourque, L. The distribution of radioactivity in the tissues of the rat after the administration of radioactive growth hormone preparations. Endocrinology 1954, 55, 709.

5. Holmberg, C. G., and Laurell, C. B. Studies on the capacity of serum to bind iron. A contribution to our knowledge of the regulation mechanism of serum iron. Acta physiol. scand. 1945, 10, 307.

6. Schade, A. L., and Caroline, L. An iron-binding component in human blood plasma. Science 1946, 104, 340.

7. Laurell, C. B., and Ingelman, B. The iron-binding protein of swine serum. Acta chem. scand. 1947, 1, 770. 
8. Goodman, M., Poulik, E., and Poulik, M. D. Variations in the serum specificities of higher primates detected by two-dimensional starch-gel electrophoresis. Nature (Lond.) 1960, 188, 78.

9. Laurell, C. B. What is the function of transferrin in plasma? Blood 1951, 6, 183.

10. Warner, R. C. Metal chelate compounds of proteins. Trans. N. Y. Acad. Sci. 1954, 16, ser. 2, 182.

11. Warner, R. C., and Weber, I. Metal-combining properties of conalbumin. J. Amer. chem. Soc. 1953, 75, 5094.

12. Schade, A. L., Reinhart, R. W., and Levy, H. Carbon dioxide and oxygen in complex formation with iron and siderophilin, the iron-binding component of human plasma. Arch. Biochem. 1949, 20, 170.

13. Surgenor, D. M., Koechlin, B. A., and Strong, L. E. Chemical, clinical, and immunological studies on the products of human plasma fractionation. XXXVII. The metal combining-globulin of human plasma. J. clin. Invest. 1949, 28, 73.

14. Koechlin, B. A. Preparation and properties of serum and plasma proteins. XXVIII. The $\beta_{1}$-metalcombining protein of human plasma. J. Amer. chem. Soc. 1952, 74, 2649.

15. Fraenkel-Conrat, H., and Feeney, R. E. The metalbinding activity of conalbumin. Arch. Biochem. 1950, 29, 101.

16. Azari, P. R., and Feeney, R. E. Resistance of the metal complexes of conalbumin and transferrin to proteolysis and thermal denaturation. J. biol. Chem. 1958, 232, 293.

17. Azari, P. R., and Feeney, R. E. The resistance of conalbumin and its iron complex to physical and chemical treatments. Arch. Biochem. 1961, 92, 44.

18. Elmlinger, P. J., Masouredis, S. P., Soni, J., Fulton, G. E., and Belknap, S. L. Plasma mixing and removal curves for $\mathrm{Fe}^{50}$ and $\mathrm{I}^{131}$ after intravenous injection of doubly labeled iron binding globulin (abstract). J. clin. Invest. 1954, 33, 930.

19. Inman, J. K. Preparation of crystalline beta-1-metalcombining protein in Tenth Conference on Plasma Proteins and Cellular Elements of the Blood. Cambridge, Mass., Protein Foundation, 1956.

20. Inman, J. K., Coryell, F. C., McCall, K. B., Sgouris, J. T., and Anderson, H. D. A large-scale method for the purification of human transferrin. Vox Sang. (Basel) 1961, 6, 34.

21. Goodman, M., Newman, H. S., and Ramsey, D. S. Use of chicken antiserum for rapid determination of plasma protein components. III. The assay of human serum transferrin. J. Lab. clin. Med. 1958, $51,814$.

22. Smithies, O. An improved procedure for starch-gel electrophoresis. Further variations in the serum proteins of normal individuals. Biochem. J. 1959, 71,585 .

23. Smithies, O. Third allele at the serum $\beta$-globulin locus in humans. Nature (Lond.) 1958, 181, 1203.

24. Hine, G. J. Isotopes: Radioactive; dosimetry of internal beta- and gamma-ray emitters in Medical
Physics, O. Glasser, Ed. Chicago, Year Book Publishers, 1960, vol. 3, p. 314.

25. Ouchterlony, O. Diffusion in gel methods for immunological analysis. Progr. Allergy 1958, 5, 1.

26. Gitlin, D. Use of ultraviolet absorption spectroscopy in the quantitative precipitin reaction. J. Immunol. 1949, 62, 437.

27. McMenamy, R. H., Lund, C. C., and Oncley, J. L. Unbound amino acid concentrations in human blood plasmas. J. clin. Invest. 1957, 36, 1672.

28. Peters, T., Giovanniello, T. J., Apt, L., and Ross, J. F. A new method for the determination of serum iron-binding capacity. I. J. Lab. clin. Med. 1956, 48, 274.

29. Peters, T., Giovanniello, T. J., Apt, L., and Ross, J. F. A simple improved method for the determination of serum iron. II. J. Lab. clin. Med. 1956, 48, 280.

30. Peters, T., and Giovanniello, T. J. A note on the serum iron determination described by Peters, Giovanniello, Apt and Ross. J. Lab. clin. Med. 1958, 51, 494.

31. Hine, G. J., Burrows, B. A., Apt, L., Pollycove, M., Ross, J. F., and Sarkes, L. A. Scintillation counting for multiple-tracer studies. Nucleonics 1955, 13 , no. $2,23$.

32. Hine, G. J., Jagger, P. I., and Burrows, B. A. Measurement of body radioactivity for studies of sodium metabolism. J. Lab. clin. Med. 1960, 55, 476.

33. Huff, R. L., Hennessy, T. G., Austin, R. E., Garcia, J. F., Roberts, B. M., and Lawrence, J. H. Plasma and red cell iron turnover in normal subjects and in patients having various hematopoietic disorders. J. clin. Invest. 1950, 29, 1041.

34. Schultze, H. E., Heide, K., and Muller, H. Uber Transferrin/Siderophilin. Behringwerk-Mitteil 1957, 32, 25.

35. Apt, L., Pollycove, M., and Ross, J. F. Idiopathic pulmonary hemosiderosis. A study of the anemia and iron distribution using radioiron and radiochromium. J. clin. Invest. 1957, 36, 1150.

36. Pollycove, M., and Mortimer, R. The quantitative determination of iron kinetics and hemoglobin synthesis in human subjects. J. clin. Invest. 1961, 40, 753.

37. Bush, J. A., Ashenbrucker, H., Cartwright, G. E., and Wintrobe, M. M. The anemia of infection. $\mathrm{XX}$. The kinetics of iron metabolism in the anemia associated with chronic infection. $\mathrm{J}$. clin. Invest. 1956, 35, 89.

38. Bothwell, T. H., Hurtado, A. V., Donohue, D. M., and Finch, C. A. Erythrokinetics: IV. The plasma iron turnover as a measure of erythropoiesis. Blood 1957, 12, 409.

39. Schultz, A. L., Hammarsten, J. F., Heller, B. I., and Ebert, R. V. A critical comparison of the T-1824 dye and iodinated albumin methods for plasma volume measurement. J. clin. Invest. 1953, 32, 107. 
40. Schreiber, S. S., Bauman, A., Yalow, R. S., and Berson, S. A. Blood volume alterations in congestive heart failure. J. clin. Invest. 1954, 33, 578.

41. Solomon, A. K. Equations for tracer experiments. J. clin. Invest. 1949, 28, 1297.

42. Katz, J. H., and Donaldson, R. Unpublished observations.

43. Korman, S. Iron metabolism in man. Ann. N. Y. Acad. Sci. 1960, 88, 460.

44. Solvell, L. Effect of transferrin intravenously on iron absorption. Acta med. scand. 1960, suppl. 358, 91.

45. Jandl, J., Inman, J. K., Simmons, R. L., and Allen, D. W. Transfer of iron from serum iron-binding protein to human reticulocytes. J. clin. Invest. 1959, 38, 161.

46. Mazur, A., Green, S., and Carleton, A. Mechanism of plasma iron incorporation into hepatic ferritin. J. biol. Chem. 1960, 235, 595.

47. Turnbull, A., and Giblett, E. R. The binding and transport of iron by transferrin variants. J. Lab. clin. Med. 1961, 57, 450.

48. Jandl, J. H., and Katz, J. H. The plasma-to-cell cycle of transferrin in iron utilization. Trans. Ass. Amer. Phycns. In press.

49. Pease, D. C. An electron microscopic study of the red bone marrow. Blood 1956, 11, 501.

50. Weiss, L. An electron microscopic study of the vascular sinuses of the bone marrow of the rabbit. Bull. Johns Hopk. Hosp. 1961, 108, 171.

51. Gitlin, D., Landing, B. H., and Whipple, A. The localization of homologous plasma proteins in the tissues of young human beings as demonstrated with fluorescent antibodies. J. exp. Med. 1953, 97, 163.

52. Cartwright, G. E., Gubler, C. J., and Wintrobe, M. M. The anemia of infection. XII. The effect of turpentine and colloidal thorium dioxide on the plasma iron and plasma copper of dogs. J. biol. Chem. 1950, 184, 579.

53. Mitchell, J., Halden, E. R., Jones, F., Bryan, S., Stirman, J. A., and Muirhead, E. E. Lowering of transferrin during iron absorption in iron deficiency. J. Lab. clin. Med. 1960, 56, 555.

54. Steinfield, J. L., Greene, F. E., Tabern, D. L., Paton, R. R., and Flick, A. L. Degradation of iodinated

I human serum albumin prepared by various procedures. J. Lab. clin. Med. 1958, 51, 756.

55. Gitlin, D., Cornwall, D. G., Nakasato, D., Oncley, J. L., Hughes, W. L., Jr., and Janeway, C. A. Studies on the metabolism of plasma proteins in the nephrotic syndrome. II. The lipoproteins. J. clin. Invest. 1958, 37, 172.

56. Gitlin, D., Janeway, C. A., and Farr, L. E. Studies on the metabolism of plasma proteins in the nephrotic syndrome. I. Albumin, $\gamma$-globulin and ironbinding globulin. J. clin. Invest. 1956, 35, 44.

57. McFarlane, A. S. Labelling of plasma proteins with radioactive iodine. Biochem. J. 1956, 62, 135.

58. Yalow, R. S., and Berson, S. A. The effect of irradiation damage of albumin- $\mathrm{I}^{131}$ on the rate of its in vivo metabolism with special reference to the validity of biologic studies with $\mathrm{I}^{131}$-labeled proteins (abstract). J. clin. Invest. 1956, 35, 746.

\section{CORRECTION}

In the paper "The Incorporation of Plasma Free Fatty Acids into Plasma Triglycerides in Man," by S. J. Friedberg, R. F. Klein, D. L. Trout, M. D. Bogdonoff and E. H. Estes, Jr., 1961, 40, 1852 (October), the following errors occurred.

$$
\begin{aligned}
& \text { For : } z=x-y \\
& \begin{array}{rr}
z=x-k \int_{t_{0}}^{t_{1}} x d t & \text { read: } z=x+y \\
F=z / M=\left[x-k \int_{t_{0}}^{t_{1}} x d t\right] / M & F=z / M=\left[x+k \int_{t^{0}}^{t_{1}} x d t\right] / M \\
F a=a / M\left[x-k \int_{t_{0}}^{t_{1}} x d t\right] & F a=a / M\left[x+k \int_{t_{0}}^{t_{1}} x d t\right] \\
\text { Plasma TGFA content } & \text { Plasma TGFA content } \\
=a / M k\left[x-k \int_{t_{0}}^{t_{1}} x d t\right] & =a / M k\left[x+k \int_{t_{0}}^{t_{1}} x d t\right] \\
=a / M\left[x / k-\int_{t_{0}}^{t_{1}} x d t\right] & =a / M\left[x / k+\int_{t_{0}}^{t_{1}} x d t\right]
\end{array}
\end{aligned}
$$

